\title{
Sputum Inflammatory Cells from Persons with Allergic Rhinitis and Asthma Have Decreased Inflammasome Gene Expression
}

\author{
Willie June Brickey, PhDa, Neil E. Alexis, PhD ${ }^{b, c}$, Michelle L. Hernandez, MD ${ }^{b, c}$, William \\ Reed, PhD ${ }^{b, c}$, Jenny PY. Ting, PhD ${ }^{a, d, e}$, and David B. Peden, MD ${ }^{a, b, c, f}$ \\ aDepartment of Microbiology and Immunology, The School of Medicine, The University of North \\ Carolina at Chapel Hill, Chapel Hill, North Carolina \\ ${ }^{b}$ Department of Pediatrics, The School of Medicine, The University of North Carolina at Chapel \\ Hill, Chapel Hill, North Carolina \\ ${ }^{\circ}$ Center for Environmental Medicine, Asthma and Lung Biology, The School of Medicine, The \\ University of North Carolina at Chapel Hill, Chapel Hill, North Carolina \\ dCenter for Translational Immunology, The School of Medicine, The University of North Carolina \\ at Chapel Hill, Chapel Hill, North Carolina \\ eLineberger Comprehensive Cancer Center, The School of Medicine, The University of North \\ Carolina at Chapel Hill, Chapel Hill, North Carolina \\ fDepartment of Medicine, The School of Medicine, The University of North Carolina at Chapel Hill, \\ Chapel Hill, North Carolina
}

\section{Capsule Summary}

Deficits in inflammasomes, a key element of innate immunity, confer increased susceptibility to infection. We report that sputum cells from asthmatics have decreased expression of inflammasome factors, consistent with reports of increased infection risk in asthmatics.

\section{Keywords}

Innate Immunity; Asthma; Atopy; Inflammasome; IL-1 $\beta$

\section{To the Editor}

There are numerous reports supporting the hypothesis that decreased exposure to microbes as well as genetic factors that attenuate innate immune responsiveness increase risk for developing asthma and atopy. A growing body of evidence also suggests that adverse health outcomes due to bacterial infection or microbial colonization in the airways may be increasing in asthmatics and other atopic persons. Numerous investigators have shown that

\footnotetext{
(C) 2011 American Academy of Allergy, Asthma and Immunology. Published by Mosby, Inc. All rights reserved.

Corresponding Author: David B. Peden, MD, Center for Environmental Medicine, Asthma and Lung Biology, 104 Mason Farm Road, UNC School of Medicine, Chapel Hill, NC 27516, peden@med.unc.edu, phone 919-966-0768, fax 919-966-9863.

Disclosures: N. E. Alexis has contracts with Centocor Pharmacueticals, GlaxoSmithKline and MedImmune. D. B. Peden has been a consultant to GlaxoSmithKline and Aquinox Pharmaceuticals and a contract with MedImmune. J. PY. Ting had a one-year contract with GlaxoSmithKline (Philadelphia). The rest of the authors have declared that they have no conflicts of interest.

Publisher's Disclaimer: This is a PDF file of an unedited manuscript that has been accepted for publication. As a service to our customers we are providing this early version of the manuscript. The manuscript will undergo copyediting, typesetting, and review of the resulting proof before it is published in its final citable form. Please note that during the production process errors may be discovered which could affect the content, and all legal disclaimers that apply to the journal pertain.
} 
asthmatics have increased risk of invasive pneumococcal disease ${ }^{(1 ; 2)}$. Additionally, persons with poorly controlled asthma have increased bacterial colonization of the airway, indicated by either increased airway endotoxin levels ${ }^{(3)}$ or elevated 16S rRNA load in bronchial samples ${ }^{(4)}$. Asthmatics also have increased lower respiratory symptoms, greater impairment of lung function and bronchial hyperreactivity, diminished circulating $\mathrm{CD} 8^{+}$lymphocytes, and deficient IFN- $\gamma$ and IL-10 responses following experimental rhinoviral infection, consistent with other studies which suggest that the severity of viral infection is increased, and that viral mechanisms to evade immune response have evolved ${ }^{(5)}$. Taken together, these observations suggest that increased disease severity in asthmatics may be associated with diminished innate immunity and increased susceptibility to viral or bacterial airway infection.

Inflammasomes are newly appreciated innate immune regulatory complexes which process IL-1 $\beta$ and Il-18 when activated by a number of pathogen, environmental or host-derived danger signals. We have made seminal observations demonstrating the important role of inflammasomes in mediating host defense against influenza and bacterial pathogens, as well as modulating responses to alum and contact dermatitis ${ }^{(6)}$. The mounting evidence that persons with asthma may have impaired innate immune responses propelled us to hypothesize that inflammasome function may be reduced in asthmatics compared to healthy non-atopic normal volunteers.

To test this hypothesis, we examined sputum samples in our sample repository from normal volunteers (NV), asthmatics (Asth, 5 with atopy), and volunteers with allergic rhinitis (AR, all with positive skin tests) recruited using protocols approved by the UNC IRB as previously described $^{(7)}$ to assess IL-1 $\beta$ and inflammasome-regulated mechanisms that alter immune responsiveness. All volunteers had normal lung function, with allergy status confirmed by history and allergen skin tests, and asthma status confirmed by clinical history and methacholine challenge (Table I). Sputum cell pellets contained predominantly macrophages (Mac) and neutrophils (PMN) with less than 10\% squamous epithelial cells (Table I). While cell counts were not significantly different between the groups, trends of double PMNs in Asth compared to the other two groups and double macrophage in AR compared to NV were evident. The sputum supernatants from asthmatic (Asth) and normal volunteers (NV) were assessed for protein levels of IL-1 $\alpha$, IL-1 $\beta$, IL-6 and TNF $\alpha$ by multiplex immunoassay (RayBiotech). Asthmatics showed decreased levels of IL-1 $\alpha$ and IL-1 $\beta$, while no significant differences in IL- 6 or TNF $\alpha$ were observed between these groups (Figure 1A).

Messenger RNA from sputum cell pellets was assayed for gene expression of inflammasome-associated genes (ASC, CARD8, CASP1, NLRP1, NLRP3, and NLRC4); noninflammasome Nucleotide-Binding Leucine-Rich Repeat factors (NLRP12, NOD1, NOD2, $B I R C 2$ ); cytokines $I L-1 \beta, I L-18, I L-6$ and $T N F \alpha$; and HLA molecules. To assess gene expression, two-color $\mathrm{cDNA}$ microarray hybridization was performed on labeled sputum RNA probes (EpiCentre) with signal intensity ratios normalized to housekeeping genes ( $\beta$ actin and 605 ribosomal RNA). Secondly, total sputum cell RNA was transcribed to cDNA using MMLV RT and amplified by quantitative PCR using gene-specific probes sets (Applied Biosystems) to assess gene expression relative to housekeeping gene $\beta$-actin.

Gene expression for the MHC molecules HLA-DPA1, HLA-A and HLA-C, and the inflammasome molecules ASC, CARD 8 and NLRC4 were significantly decreased in Asth and AR compared to NV, with $C A S P 1$ trending toward reduced levels in Asth compared to NV (Figure 1B). Additionally, NOD2 and BIRC2 expression was lower in Asth compared to $\mathrm{NV}$, while expression of $N L R P 1, N L R P 3, N L R P 12$, and $N O D 1$ did not vary significantly between groups. Lowered gene expression for $I L-1 \beta, I L-18$ and $T N F \alpha$ was evident in Asth 
and AR. In comparison, real-time PCR results showed significantly diminished expression of ASC, CARD8, NLRC4, CASPI and TNF $\alpha$ in Asth and AR versus NV, with trends of lowered $I L-1 \beta, H L A-D P A 1$ and $H L A-C$ expression (Figure 1C). While the results between microarray and PCR analyses mostly align, there are discrepancies that might be attributed to technical issues such as dissimilar oligonucleotide targets between microarray and PCR methods used for transcript detection and/or disparate efficiencies in measuring low abundant or degraded transcripts. Gene-specific PCR amplification may provide a more accurate representation of sputum cell expression due to sensitive detection.

Our results are consistent with the hypothesis that relative to NV, Asth and AR volunteers display reduced innate immune capability. Specifically, we found diminished airway cell expression of inflammasome components ASC, CARD8, and NLRC4 as well as IL-1 $\beta$, the key mediator released following inflammasome activation, in both Asth and AR groups. However, we were unable to determine gene expression of specific cell types in sputum, or which cell type might account for decreased gene expression in Asth and AR groups. Eosinophils, which are more typical in sputum atopic persons, have less expression of inflammasome genes than dendritic cells, neutrophils or macrophages ${ }^{(8)}$. Also, we were unable to differentiate M1 from M2 macrophages in this study. Macrophages can be polarized to the $\mathrm{M} 2$ phenotype by the $\mathrm{TH}_{2}$ cytokines IL- 4 and IL-13, and have decreased inflammasome activity with decreased IL-1 $\beta$ secretion compared to M1 ${ }^{(9)}$. Since macrophages were the most abundant cell in sputum from each group, and M2 macrophages are more likely to be present in atopic persons, we hypothesize that M2 macrophages in the airways of Asth and AR volunteers may account for the observed diminished sputum cell inflammasome gene expression. Finally, it is not known if upon appropriate stimulation, inflammasome expression would increase in cells from asthmatic and atopic patients.

In summary, our pilot data support the hypothesis that development of asthma and atopic diseases is associated with decreased inflammasome function. Future studies will focus on determining inflammasome gene expression and function in isolated sputum macrophages and granulocytes from asthmatics and atopic persons, and the relationship between $\mathrm{TH}_{2}$ cytokines, the expression and function of inflammasome complexes, and asthma disease severity.

Sincerely,

Willie June Brickey, $\mathrm{PhD}^{\mathrm{a}}$, Neil E. Alexis, $\mathrm{PhD}^{\mathrm{b}, \mathrm{c}}$, Michelle L. Hernandez, $\mathrm{MD}^{\mathrm{b}, \mathrm{c}}$, William Reed, PhD ${ }^{\mathrm{b}, \mathrm{c}}$, Jenny PY. Ting, PhD ${ }^{\mathrm{a}, \mathrm{d}, \mathrm{e}}$, and David B. Peden, MD ${ }^{\mathrm{a}, \mathrm{b}, \mathrm{c}, \mathrm{f}}$

a. Department of Microbiology and Immunology

b. Department of Pediatrics

c. Center for Environmental Medicine, Asthma and Lung Biology

d. Center for Translational Immunology

e. Lineberger Comprehensive Cancer Center

f. Department of Medicine

The School of Medicine

The University of North Carolina at Chapel Hill

Chapel Hill, North Carolina 


\section{Acknowledgments}

Funding Sources: W.J.B., N.E.A., W.R., J.PY.T., D.B.P. are supported by NIAID U19AI077437. MLH is supported by NIH KL2RR025746

\section{Abbreviations}

$\begin{array}{ll}\text { FEV }_{\mathbf{1}} & \text { Forced Expiratory Volume in One Second } \\ \text { PD }_{20} & \text { provocative dose causing 20\% reduction in airflow } \\ \text { Asth } & \text { asthmatic } \\ \text { AR } & \text { allergic rhinitic } \\ \text { NV } & \text { normal volunteer } \\ \text { PMN } & \text { neutrophil } \\ \text { Mac } & \text { macrophage } \\ \text { Lym } & \text { lymphocyte } \\ \text { Eos } & \text { eosinophil } \\ \text { BEC } & \text { basal endothelial cell }\end{array}$

\section{References}

1. Juhn YJ, Kita H, Yawn BP, Boyce TG, Yoo KH, McGree ME, et al. Increased risk of serious pneumococcal disease in patients with asthma. J Allergy Clin Immunol. 2008; 122(4):719-23. [PubMed: 18790525]

2. Talbot TR, Hartert TV, Mitchel E, Halasa NB, Arbogast PG, Poehling KA, et al. Asthma as a risk factor for invasive pneumococcal disease. N Engl J Med. 2005; 352(20):2082-90. [PubMed: 15901861]

3. Goleva E, Hauk PJ, Hall CF, Liu AH, Riches DW, Martin RJ, et al. Corticosteroid-resistant asthma is associated with classical antimicrobial activation of airway macrophages. J Allergy Clin Immunol. 2008; 122(3):550-9. [PubMed: 18774390]

4. Huang YJ, Nelson CE, Brodie EL, Desantis TZ, Baek MS, Liu J, et al. Airway microbiota and bronchial hyperresponsiveness in patients with suboptimally controlled asthma. J Allergy Clin Immunol. 2011; 127(2):372-81. [PubMed: 21194740]

5. Newcomb DC, Peebles RS Jr. Bugs and asthma: a different disease? Proc Am Thorac Soc. 2009; 6(3):266-71. [PubMed: 19387028]

6. Davis BK, Wen H, Ting JP. The Inflammasome NLRs in Immunity, Inflammation, and Associated Diseases. Annu Rev Immunol. 2010

7. Alexis NE, Brickey WJ, Lay JC, Wang Y, Roubey RA, Ting JP, et al. Development of an inhaled endotoxin challenge protocol for characterizing evoked cell surface phenotype and genomic responses of airway cells in allergic individuals. Ann Allergy Asthma Immunol. 2008; 100(3):20615. [PubMed: 18426139]

8. Guarda G, Zenger M, Yazdi AS, Schroder K, Ferrero I, Menu P, et al. Differential expression of NLRP3 among hematopoietic cells. J Immunol. 2011; 186(4):2529-34. [PubMed: 21257968]

9. Pelegrin P, Surprenant A. Dynamics of macrophage polarization reveal new mechanism to inhibit IL-1beta release through pyrophosphates. EMBO J. 2009; 28(14):2114-27. [PubMed: 19536133] 


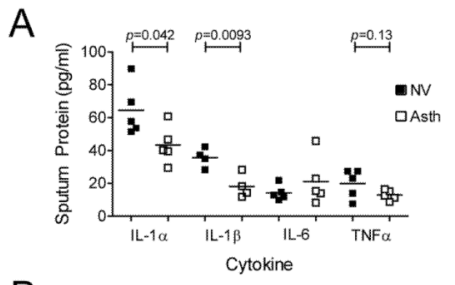

$B$
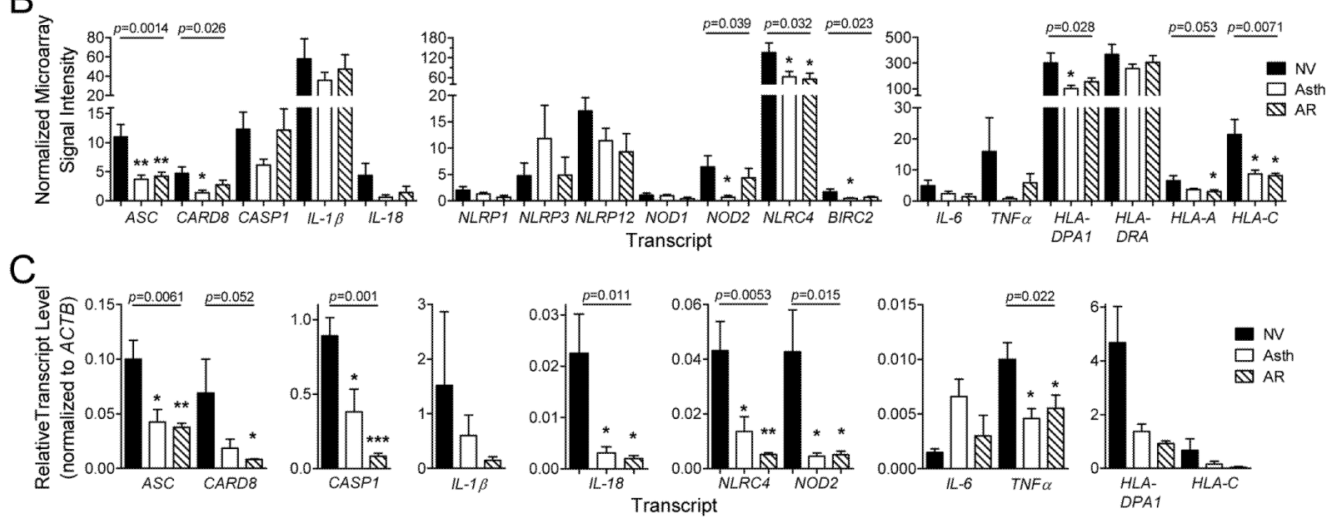

Figure 1.

Assessment of innate immune factors in sputum airway cells. (A) Sputum supernatant protein for NV and Asth subjects are analyzed by multiplex ELISA with mean levels indicated by bar. Gene expression is assessed by oligonucleotide microarray hybridization (B) and PCR analyses (C). Mean normalized microarray signal intensity ratio of experimental to universal reference RNA \pm SEM in NV, Asth and AR are plotted ( $n=8-10$ / group). Mean PCR-amplified transcripts relative to $A C T B \pm$ SEM are plotted ( $n=5 /$ group). Statistical tests include (A) Unpaired $t$ test and (B, C) One-way Analysis of Variance for three groups (with overall $p$ values depicted over the line) with Dunnett's Multiple Comparison Test to NV (stars) with $p$ values indicated $(* p<0.05, * * p<0.01, * * * p<0.001)$. 


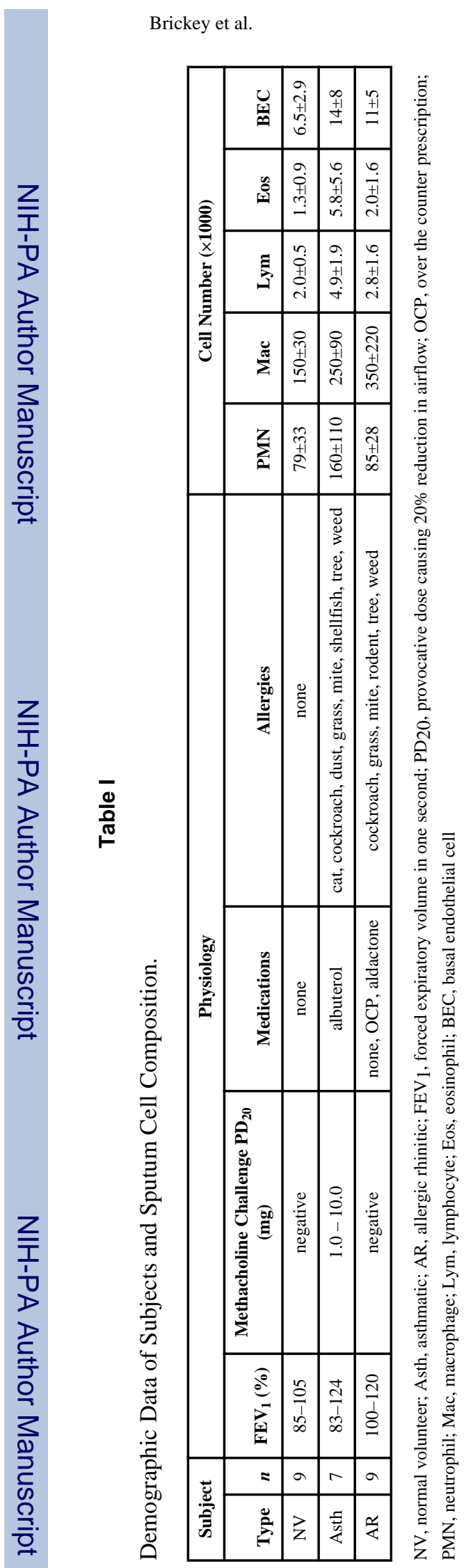

Page 6 